\title{
It's all about the Flex: Preference, Flexibility and Power in the Employment of EU Migrants in Low-Skilled Sectors
}

\author{
Heather Rolfe
}

National Institute of Economic and Social Research

E-mail: H.Rolfe@niesrc.ac.uk

In the last ten years, EU migrants have come to play an important role in the UK labour force. They have become increasingly present in low-skilled occupations, where the largest proportional increase has been migration from Eastern and Central European countries. Drawing on research carried out between November 2015 and July 2016 on the employment of EU migrants in the sectors of hospitality, food and drink and construction, we find that EU migrants have met employers' needs for a flexible labour force but that the use of mobile workers in these sectors is long-standing. The prospect of a reduced supply of EU migrants following the UK's vote to leave the EU and the government's target of reducing net migration poses a challenge for employers. We explore the tension between political pressure and economic need through posing a range of options for new immigration policy post-Brexit.

Keywords: Brexit, employment, immigration policy, migration.

\section{Introduction}

In the last ten years, EU migrants have come to play an important role in the UK labour force. They have become increasingly present in low-skilled occupations, where the largest proportional increase has been migration from Central and Eastern Europe. Surveys indicate that most employers who have hired migrants plan to continue to do so, seeing them as having a permanent place in the workforce (Rolfe et al., 2013; CIPD, 2014; Wadsworth, 2014). However, the decision to leave the EU in the 2016 referendum has called into question employers' future access to migrant labour. The impact, through new policies, on existing EU migrants, in relation to their continuing right to work in the UK is currently unknown. However, because of the Conservative Party's commitment to reduce immigration levels to the tens of thousands, and the belief that public concerns must be addressed, it seems likely that free movement will end. This makes a review of the place of migrant labour in the UK's economy, and the scope for alternatives, a timely exercise.

Previous research, which focused on jobs and wages, found very little impact from migration, either EU or non-EU, when measured statistically. Any effects were found to be very small (Dustmann et al., 2005; Nickell and Saleheen, 2008; Manacorda et al., 2011; Dustmann and Frattini, 2013; Migration Advisory Committee, 2014). A comprehensive evidence review by the UK Government found little evidence of a statistically significant impact on native employment outcomes from EU migration (Devlin et al., 2014). While econometric evidence suggests that the impact on jobs and wages are relatively small, some features of the labour market and its institutions appear to have changed alongside the increase in EU migration. Over the course of the past ten years, the nature of the UK 
labour market has changed considerably, with rapid growth in self-employment and in other 'flexible' modes of employment such as zero hours contracts and employment via agencies. Relatively little is known about how migration, in particular intra-EU migration, has affected these developments.

Linked to this, existing research has explained the proliferation of migrants in lowskilled sectors with reference to a preference for such workers by employers who operate with stereotyped ideas of their higher productivity and compliant attitude (Scott, 2013; McCollum and Findlay, 2015). Some studies report a 'preference' among employers for migrants, using concepts such as 'hiring queues' (Scott, 2013) in which groups are ordered ethnically to explain employers' apparent preferences. 'Attitude' and work ethic are regarded as key distinguishing factors used by employers in their hiring decisions (Ruhs and Anderson, 2010; McCollum and Findlay, 2015; Markova et al., 2016). Others find that employers do not have such preferences but recruit simply to fill vacancies (Green et al., 2013). Much of the research does not explore employers' approaches in sufficient depth, or use employers' own accounts of their practices. This article draws on research carried out both in the lead up to the referendum vote, and in the period immediately after. We look first at the role of EU migrants in meeting employers' skills and labour needs over the last ten years. Our main question is whether access to migrant labour has changed the nature of employment, particularly in the low-skilled sectors, and what alternatives employers have. We examine why employers recruit EU migrants and the evidence in support of ethnic queuing. We also examine whether the mobility of these workers lends them a form of power in the current economic and political context. We conclude that the concept of 'ethnic queuing' finds limited support in the empirical evidence and that the characteristics of the low-skilled labour market have to some degree empowered mobile workers. The article then looks at the implications of Brexit for employers of EU migrants and options for future immigration policies, arguing that the decision for policy-makers is not whether migrants should continue to meet the UK's low-skilled labour needs, but what form immigration should take.

\section{The role of migrants in meeting the UK's low-skilled labour needs}

As writers on migration frequently point out, the use of migrant labour in low-skilled sectors is not new: sizeable numbers of migrants have been recruited to work in sectors such as manufacturing and transport since the post-war period. ${ }^{1}$ Despite the supply of labour from the Commonwealth and from Ireland, some industries experienced regular and persistent shortages, in particular the industries associated with food production agriculture, food manufacturing and hospitality. As well as employing migrants, these sectors have historically recruited from other groups in the secondary labour market, such as students and workers displaced from traditional industries, for example coal mining (Lucas and Mansfield, 2008).

From 2004, citizens of the eight accession countries in Central and Eastern Europe (A8) were given full rights to live and work in the UK. ${ }^{2}$ The period from 2004 onwards has seen a steady increase in migration from these countries, followed in 2014 by citizens of Romania and Bulgaria (A2), who had been subject to transitional controls for seven years. A new points-based system was introduced in 2008 with provision for unskilled migration - Tier 3. However, this was never implemented because by that time EU migration, combined with sector-specific schemes, was meeting the UK's additional labour needs. 


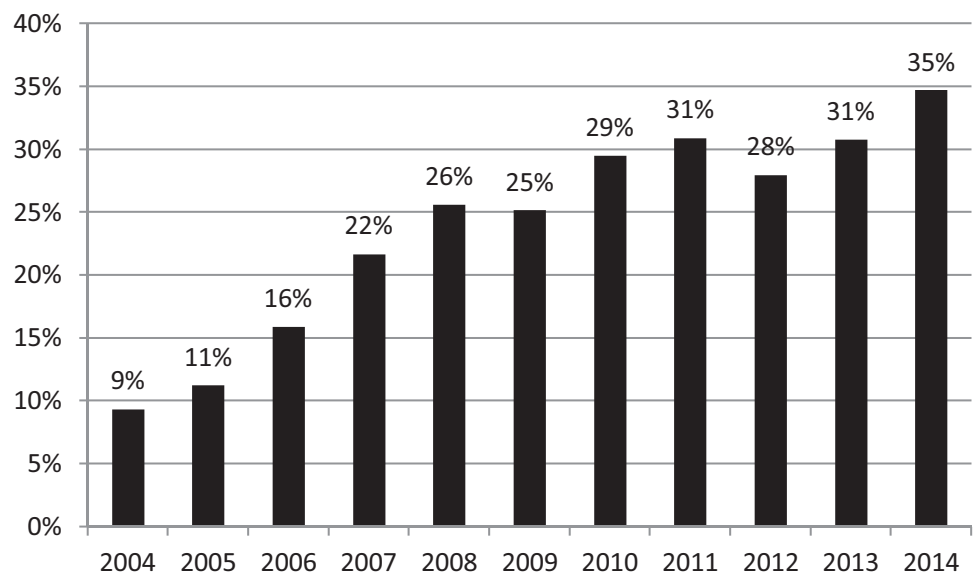

Figure 1. Proportion of migrants working in UK food and drink manufacturing Source: Labour Force Survey.

Migration from central and Eastern Europe has changed the skills profile of migrant employment. As recently as 2002, only one low-skilled occupation was listed in the top ten jobs with the highest share of foreign-born workers. This was food preparation trades, which at that time had a sector-based scheme (Migration Advisory Committee, 2014). By 2014, half of the top ten jobs with the highest proportions of foreign-born workers were low-skilled occupations, including cleaning and housekeeping, food preparation and hospitality, assemblers and routine operatives (Rienzo, 2015). The food manufacturing sector still has the highest share of foreign-born workers, accounting for 35 per cent of employees, up from around 8.5 per cent in 2002 (see Figure 1).

A third of migrants from the Central and Eastern European accession states (A8 countries) are in elementary, unskilled occupations, while EU migrants from older member states are strongly represented in highly skilled occupations. Those from newer member states are also over-represented in skilled manual trades, where around one in six is employed, compared to close to one in ten of UK-born workers (Wadsworth, 2014). Partly because of this bi-polar distribution, EU workers are also unevenly distributed across the UK. While those from older member states are concentrated in London and the South East, those from Central and Eastern Europe are more widely distributed across the UK (Hawkins, 2016). This is accounted for by the granting of free movement to Central and Eastern European member states at a time of low unemployment in the UK; and by the role that employment and recruitment agencies played in sourcing migrants to work in locations across the country (Metcalf et al., 2008). This wide distribution is important as it indicates that restrictions on EU migration are likely to be felt across the UK as well as by the specific industries where they are concentrated.

\section{Methods and choice of sectors}

Our research was based on interviews before the referendum with twenty-four employers within the construction industry, food and drink processing and hospitality industry. 


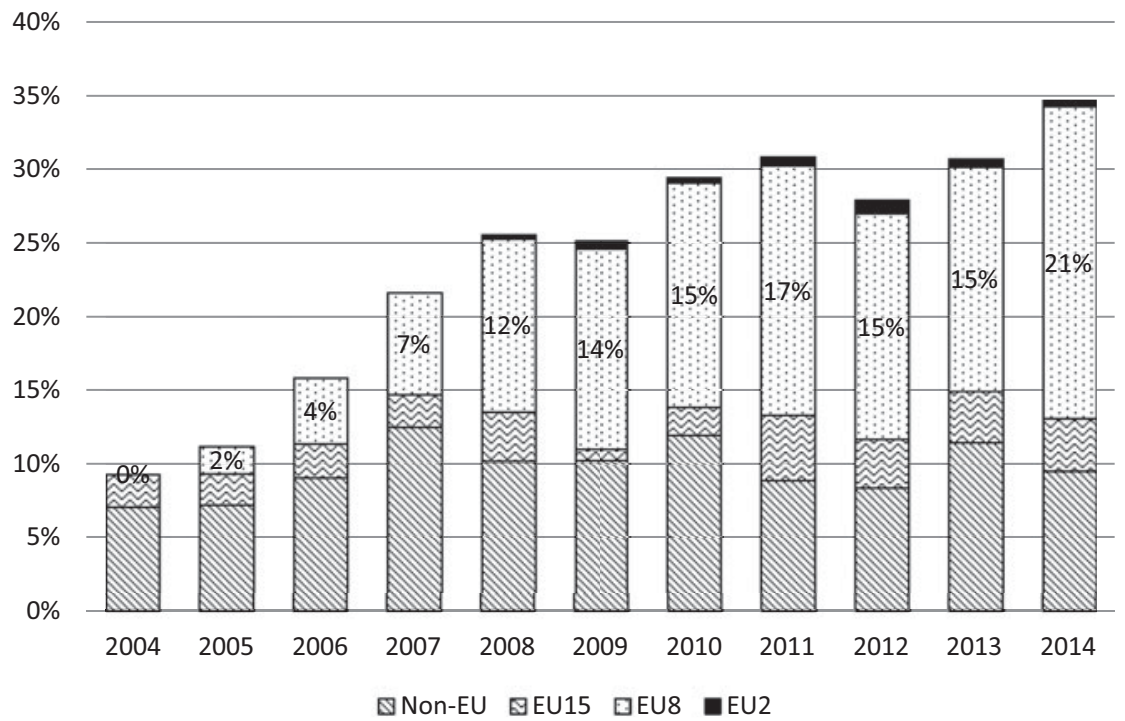

Figure 2. Proportion of migrants working in UK food and drink manufacturing, by EU and non-EU status Source: Labour Force Survey.

Seventeen of these were followed up after the referendum. We chose companies in the above sectors because of the increase in EU migrant workers in these sectors. Their presence is strongest in food processing, with Figure 1 showing how the proportion of migrant labour in this sector grew rapidly from 2004 to the point where they account for a third of the workforce. Figure 2 shows how this is accounted for by migrants from Eastern Europe. The industry includes a high proportion of small businesses and is widely distributed geographically across the UK, including in small towns and rural areas (Geddes, 2008). Importantly, it is also seasonal with a fluctuating demand for labour.

The hospitality sector, which includes hotels and restaurants, has undergone substantial growth in recent years and is one of the largest employers of migrant workers, accounting for 28 per cent of the sector's employees. Other features of the hospitality sector include an over-representation of women, at around 60 per cent of the labour force; a younger than average age profile; a proliferation of part-time opportunities; and extensive use of temporary and flexible contracts, including those offered on a 'zero hours' basis. The seasonal nature of parts of the sector and fluctuating demand for labour drive the use of these arrangements (Markova et al., 2016). The sector has experienced long-term skills gaps (Institute of Hospitality, 2011).

The construction industry has a high demand for skilled workers and highly skilled professionals as well as for the lower level skills. Many workers in the sector lack formal qualifications. Migrants are over-represented in low-skilled work and there is evidence of under-utilisation of high-level skills (Chan et al., 2008). Overall, the sector's use of migrant workers is low, at 12 per cent, but in London they account for more than half of the construction workforce. It is a volatile sector with fluctuating demand for labour which has promoted the use of temporary employment. The business model of the industry is based on sub-contracting into smaller units of work, and self-employment is common. 
We selected twenty-four case study companies using on-line directories of employers to include a range by size and location. They therefore included small, medium and large firms located across the UK, including Wales and Scotland and in urban and rural areas. Despite this range, we do not claim that the companies are representative of their sectors. However, even with the relatively small number interviewed, responses to some questions showed a strong degree of uniformity, in particular those relating to reasons for employing EU migrants. Most interviewees were human resource managers or, in smaller companies, the chief executive. Interviews took up to one hour, were carried out by telephone and transcribed verbatim. We analysed the qualitative interview data thematically using a framework approach (Ritchie and Lewis, 2013). The analysis drew out differences both between and within sectors, exploring these in relation to existing literature and theoretical frameworks.

Among the hospitality case studies, the proportion of EU migrants employed ranged from very low at just a handful of workers or fewer, to more than 25 per cent, but in one case migrant workers represented more than 90 per cent of the workers. In businesses with a seasonal element, the proportion of EU migrants rose significantly at busy times of year, for example from 25 per cent to 45 per cent during the high season. Five of the six food and drink manufacturing companies reported an EU migrant workforce of more than 30 per cent, with seasonal workers boosting the EU migrant workforce. Reflecting the industry as a whole, the proportion of EU migrants employed by the construction companies was lower than the other two sectors, at 10 per cent or less in most cases. However, where labour demand fluctuated, EU migrants were reported to form a higher proportion of the workforce.

\section{Research findings}

Employers recruit EU migrants because they are available, rather than from preference

Where migrants were significantly represented in companies, this was not explained by preference for migrants, either generally or for specific groups. Rather, it was explained by difficulty in recruiting British workers. The varying proportion of migrants in our case study firms was explained by location and the ease or difficulty with which they could recruit local, British workers. But wherever they were located, employers said they were often hiring migrants in jobs for which it is otherwise hard to recruit. Factors discouraging British applicants include intrinsic aspects of the work such as its physical nature as well as pay, contracts and limited promotion prospects. We found little evidence that employers look specifically to recruit EU migrants, which might be evidenced for example through use of agencies based overseas or recruitment largely by word of mouth. For example, a cake manufacturer in the South West explained:

We recruit workers first and then the nationality they come with is secondary. The problem we have in the South West is that we are almost as a local area at full capacity employment, so we don't have enough local people applying for jobs when we advertise them.

We also explored issues of work ethic and orientation to work, an issue which attracts media interest, but on which evidence is mixed. When we asked how the job performance 
of EU migrants compares to that of British workers, employers' most common response was there is no difference on measures such as productivity, work ethic and commitment. These differences were seen to be individual rather than attributable to nationality or migration status. Rates of turnover were also reported to be similar between EU workers and their British colleagues. As an employer in the hospitality sector remarked:

I think there's a lot of anecdotal stereotyping goes on ... We've got lots of great migrants with great work ethic and great attitude and values and also have English workers like that as well.

Where any differences in attitude were noted, these were explained with reference to migrants' motivations to improve their lives or because of their higher levels of education. It was not uncommon for EU migrants to be reported as working beneath their level of qualification, at least initially. Differences in attitude and effort were also noticed where hard physical work was involved, particularly in construction. Employers also see disadvantages in recruiting migrants, particularly language skills and company image.

\section{The flexibility of migrants aligns closely with business models}

While employers did not see significant differences in productivity or value added by the EU migrants they employed, compared to UK workers, they did identify an important difference in the degree to which EU workers work flexibly. We found the main benefit of EU migrants to employers in low-skilled sectors to be their flexibility rather than their cost or productivity. Flexibility, particularly in working hours, is of benefit where operations are subject to fluctuations in demand. All three of our sectors experienced such swings which were best accommodated by employing labour in flexible ways, pushing hours up and down according to business needs. This has been noted by existing research on the food and drink industry, which has linked the growth in migrant employees, in response to seasonality in demand (Ci Research, 2008), to around 2005, coinciding with the first arrivals from Central and Eastern Europe. During that decade, large food retailers exerted downward pressure on prices resulting in tighter profit margins in the food industry (Geddes, 2008), which in turn put pressure on wage costs and led to increased use of flexible and temporary contracts (Scott, 2013).

It is the need for flexibility resulting from business fluctuations and uncertainty that appears to explain the growth and proliferation of EU migrants in key sectors, including hospitality, construction and food and drink. The availability of EU migrant labour appears to have enabled the food sector to grow in a way which might otherwise not have been possible. The hospitality sector also experiences marked seasonal variation in demand for labour, which has been met by the supply of migrant labour for many years. The construction industry also places a premium on flexibility, and the increased presence of migrants in the sector, particularly in London, has been explained with reference to fluctuations in demand for labour resulting from market volatility and building project size. It is also seasonal to an extent (Chan et al., 2008). Also in relation to the construction sector Meardi et al. (2012) argue that mobility, rather than wages, is more valuable to employers and that the most attractive feature of migrant workers is their flexibility.

Our research adds further evidence that migrants are able to provide the flexibility that meets employers' needs in ways which are more difficult for British workers. Moreover, employers see this flexibility as a key benefit of employing EU migrants. Disincentives 
for flexible working include in-work tax credits and childcare, and these are of less significance to EU migrants than to British workers. The flexibility premium offered by migrants provides a stronger explanation of hiring practices than ideas of 'preference' or 'ethnic queuing', which suggest a purposeful strategy of targeting some groups and rejecting others. There can be little doubt that migrants have helped employers in some sectors to exercise the flexibility they require to meet business needs. This has led to the use of temporary contracts, especially in the hospitality industry, but also to the use of permanent contracts with hours that could be flexed up and down, widely referred to as 'zero hours' contracts. Self-employment is the preferred contracting arrangement in construction, again driven by the need for flexibility arising from fluctuating demand and business uncertainty.

\section{Employers' concerns at the potential loss of EU migrants}

We asked employers both before and after the referendum about what they would do if the UK were to leave the EU and restrictions were imposed on the supply of EU migrants. In the short term, some employers were concerned that EU migrants currently present in their workforce might lose their right to live and work in the UK. In the longer term, some employers were concerned about their ability to fill vacancies, with the timescale for concern varying according to their current stock of workers and levels of staff turnover. A number of employers said that restrictions on the number of migrants in low-skilled work would exacerbate their long-term and chronic recruitment difficulties and labour shortages. Some, particularly in hospitality, were not only concerned at the number of employees they could recruit, but their quality. As the manager of a holiday resort company explained:

We want to have choice, not just take anybody who applies. We don't get enough applicants to be able to give us that sort of choice. We're a small town and it's very much a tourism business, so a lot of demand for people to work here in the summer and we struggle to recruit.

Employers were exploring ways of attracting more British workers. Each sector was seen to have its own challenges but employers in all sectors identified a need for more clearly defined career pathways and career opportunities to attract school-leavers. While they had been considering this challenge for some time, the referendum had undoubtedly moved it much higher up the business agenda. Companies were also reviewing their pay structures and wider reward packages to prepare themselves for the fall in EU migrant workers and the challenge of recruiting British workers.

The referendum result appears to have led employers more openly to acknowledge and express the value of EU migrants to their organisations. Indeed, the initial response of many employers was to take action to retain their existing EU workers out of concern that the 'Leave' result would accelerate their early departure. Some employers were taking steps to retain them, including through supporting their applications for permission to remain and citizenship. For some companies, these plans entailed sizeable costs: with one company expecting that almost 800 staff might take up an offer of assistance, requiring additional company resources or legal service fees. Other employers reported that some of their workers were leaving either to return to their home countries, or to jobs vacated by others and which paid a little more. As jobs in the UK become less attractive to 
migrants, because of exchange rate changes and perceived hostility towards migrants, their bargaining power may increase. These developments may therefore undermine notions of a simple match between temporary employment and migrant labour in sectors such as hospitality. The uncertainty brought on by the referendum result, while potentially undermining that power by ending free movement, is highlighting the degree to which employers are dependent on their continued presence in the workforce.

\section{Future immigration policies}

The value of EU migrants to employers in our case study sectors was also evidenced by their responses to questions about what future immigration policies might work for them, if free movement were to end. At the time of the interviews in summer 2016, employers' main concern was to retain their current EU workers whose longer term right to remain in the UK was not clear at that time (and still is not, a year later). Their second concern was to keep free movement if at all possible. A number of employers across the three sectors said it was essential to keep EU borders open for businesses like theirs to thrive, or even survive. A manager in the construction industry stated:

We'll have no alternative because we've got a massive skill shortage in the UK, especially on our trades, including down the lower end like pipefitters, welders, steel erectors, there's a massive shortage of labour. If we couldn't use that freedom then we'd never build any power stations.

Some employers believed that free movement would continue because access to the single market would need to be retained, to prevent economic decline. Whether or not such access will be continued, some employers believe that negotiations to leave the EU will not result in any real change in relation to immigration, and that free movement will stay in some form, again from economic necessity. One employer remarked:

An end to free movement will massively affect industries like hospitality and agriculture and that won't be allowed to happen.

At the same time, employers were aware that free movement was a significant deciding factor in the vote to leave and that the Government needed to respond accordingly, as another employer noted:

We need something that allows the Government to say that they are no longer allowing the free movement of people but which is. It won't be the same free movement as people have now, if you follow what I mean and it has to be fudged around the edges.

Other employers shared these concerns that public expectations and economic necessity were at odds and will not easily be reconciled. They also saw a challenge for the UK Government in developing policies which take account the need for lowskilled labour when, as we described earlier, policies designed to meet such needs ended some years ago. While initially, statements following the referendum focused strongly on skills, the Government has informally indicated that provisions will be made for low- 
skilled labour needs, with the Brexit secretary David Davies quoted as saying that future immigration policy will need to consider:

all levels of skill ... what's necessary for universities, what's necessary for business, and what's necessary for fruit picking. (Guardian, December 2016)

Other recent comments by the Prime Minister, Chancellor and Home Secretary also indicate a recognition that low-skilled labour needs will need to be considered (Portes and Forte, 2016).

Our post-referendum interviews suggest that employers are willing, in principle, to work with any new immigration system which retains their access to the labour they need. While concerned about the cost and bureaucracy that might be involved in sectorbased schemes or a visa-based system, their main concerns were that the supply might be severely restricted, and that they would lose many of their current employees. These discussions also highlighted an issue for employers, that is the mobility power of their EU workers, which, as Alberti (2014) argues, gives migrants the ability to act strategically (Batnitzky and Mcdowell, 2013) and which could therefore be exercised should the terms of new immigration policies be seen as unfavourable to EU citizens. In particular, some employers were concerned that lengthy and costly visa application processes would discourage potential migrants from considering the UK over other options within the EU. The manager of a budget holiday chain remarked:

At the minute [the UK is] very popular because overall we have a good living standard. But when you throw other factors in to the decision making, i.e. it is difficult to get a visa, it takes too long to get a visa, is it worth it if I just want to come and work for three months?

Therefore, any new immigration arrangements, for example restrictions on settlement, on the rights of dependents might have the effect of deterring prospective migrants, at least from within the EU. Additional factors which might impact on future migration from EU countries include exchange rate changes, reduced opportunities resulting from Brexit's impact on employment and additionally legal and psychological factors surrounding uncertainty about migrants' rights to stay. The wider social climate and expressions of hostility and violence towards migrants is a further factor in determining whether migrants utilise their mobility power and choose not to work in the UK (Portes and Forte, 2016).

\section{Conclusions}

The history of immigration policy in the UK shows reliance on migrants to meet labour, as well as skills shortages, and this has led to their growth within sectors such as food processing and hospitality in recent years. Research evidence shows that employers recruit migrants because they are available and not from preference: claims that migrants are recruited because they have a better work ethic are over-stated and theories of 'ethnic queuing' based on ideas of preference lack foundation in evidence from our own study and other recent research. At the same time, migrants meet employers' needs for flexible labour in ways which are often more difficult for British workers. Migrants' flexibility, in particular to increase or reduce hours to match business needs is the only difference with native labour which employers consistently identify. 
While there are ways in which employers can reduce their reliance on EU migrant labour, employers in low-skilled sectors face considerable challenges given the features of their industries. These include low pay, limited prospects and, in food and drink and construction, unpleasant working conditions. Brexit offers employers a new incentive to improve their employment offer to attract more British workers, including opening up career pathways and development opportunities. However, the industries we have looked at will always require a large pool of unskilled workers, which historically has not been met by British workers alone. Consequently, for the future prospects of these sectors to be assured, some solution which enables them to continue to draw on EU migrant labour seems necessary.

In drawing up new immigration policies for a post-Brexit Britain, policy-makers therefore continue to face the seventy year-long challenge from the post-war period onwards of meeting the UK's economic needs and reconciling public opinion. The response to this challenge has resulted in an approach described as the 'two pillars of limitation and integration' (Somerville et al., 2009), where the former refers to cutting down levels of immigration and the latter has mainly taken the form of the passing of antidiscrimination legislation. It is important to note that public attitudes to immigration are based at least to some extent on inaccurate understanding of its scale and impacts (Rolfe et al., 2016). Despite this, the policy of limitation looks certain to continue, particularly if the Government keeps to its target of reducing net migration. It will be torn in two directions to meet public expectations and the needs of employers. Meanwhile, EU workers may decide to exercise their own labour mobility power and leave the UK for more welcoming pastures.

\section{Notes \\ 1 Of course, Irish labour was used in the Victorian period for building railways and canals. \\ 2 Poland, Lithuania, Latvia, Hungary, Slovenia, Slovakia, Czech Republic, Estonia.}

\section{References}

Alberti, G. (2014) 'Mobility strategies, "mobility differentials" and "transnational exit": the experiences of precarious migrants in London's hospitality jobs', Work, Employment and Society, 28, 6, 865-81.

Batnitzky, A. and Mcdowell, L. (2013) 'The emergence of an "ethnic economy"? The spatial relationships of migrant workers in London's health and hospitality sectors', Ethnic and Racial Studies, 36, 12, 1997-2015.

Chan, P., Clarke, L. and Dainty, A. (2008) 'Staff shortages and immigration in construction', Report prepared for the Migration Advisory Committee, Migration Advisory Committee (MAC), London.

Ci Research (2008) 'The role of migrant workers in the food and drink Manufacturing industry', Report for Improve, Food and Drink Sector Skills Council, 1-152, http://www.researchonline.org.uk/sds/ search/go.do?action=document\&ref=B10494 [accessed 28.12.2016].

Chartered Institute of Personnel and Development (CIPD) (2014) 'The growth of EU labour: Assessing the impact on the UK labour market', CIPD, http://www.cipd.co.uk/binaries/the-growth-of-eulabour-assessing-impact-uk-labour-market_2014.pdf [accessed 28.12.16].

Devlin, C., Bolt, O., Patel, D., Harding, D. and Hussain, I. (2014) Impacts of Migration on UK Native Employment: An Analytical Review of the Evidence, London: Department for Business, Innovation and Skills.

Dustmann, C., Fabbri, F. and Preston, I. (2005) 'The impact of immigration on the UK labour market', Economic Journal, 115, 324-41. 
Dustmann, C. and Frattini, T. (2013) 'The fiscal impact of immigration to the UK', The Economic Journal, $124,580,593-643$.

Geddes, A. (2008) 'Staff shortages and immigration in food processing', Report prepared for the Migration Advisory Committee, Migration Advisory Committee (MAC), London.

Green, A., Atfield, G., Adam, D. and Staniewicz, T. (2013) 'Determinants of the composition of the workforce in low skilled sectors of the economy, Warwick Institute for Employment Research Report to the Migration Advisory Committee, https://www.gov.uk/government/uploads/system/uploads/ attachment_data/file/257272/warwick-insti.pdf [accessed 12.11.2016].

Guardian (2016) 'Brexit plan will not be published before February, says David Davis', https://www. theguardian.com/politics/2016/dec/14/brexit-plan-will-not-be-published-until-february-says-davis [accessed 15.12.2016].

Hawkins, O. (2016) Migration Statistics Briefing Paper Number SN06077, 2 December.

Institute of Hospitality (2011) The Case of Recruiting and Retaining Older Workers in Hospitality, https://www.instituteofhospitality.org/Knowledge_Pack_HOSPITALITY_Dec2011_v2 [accessed 28.12.2016].

Lucas, R. and Mansfield, S. (2008) 'Staff shortages and immigration in the hospitality sector', Report to the Migration Advisory Committee, http://www.researchonline.org.uk/sds/ search/download.do?ref=B13274 [accessed 12.11.2016].

Manacorda, M., Manning, A. and Wadsworth, J. (2011) 'The impact of immigration on the structure of wages: theory and evidence from Britain', Journal of the European Economic Association, February, 10, 1, 120-51.

Markova, E., Paraskevopoulou, A., Williams, A. and Shaw, G. (2016) 'Migrant workers in small London hotels: employment, recruitment and distribution', European Urban and Regional Studies, 23, 3, 406-21.

McCollum, D. and Findlay, A. (2015) "Flexible" workers for "flexible" jobs? The labour market function of A8 migrant labour in the UK', Work Employment and Society, 29, 3, 427-43.

Meardi, G., Martín, A. and Riera, M. L. (2012) 'Constructing uncertainty: unions and migrant labour in construction in Spain and the UK', Journal of Industrial Relations, 54, 1, 5-21.

Metcalf, H., Rolfe, H. and Dhudwar, A. (2008) Employment of Migrant Workers: Case Studies of Selected Employers in Wales and Scotland, Report to Scottish and Welsh Governments, London: NIESR.

Migration Advisory Committee (MAC) (2014) Migrants in Low-Skilled Work: The Growth of EU and Non-EU Labour in Low-Skilled Jobs and Its Impact on the UK, London: MAC.

Nickell, S. and Saleheen, J. (2008) 'The impact of immigration on occupational wages: evidence from Britain', Federal Reserve Bank of Boston Working Paper No. 08-6.

Portes, J. and Forte, G. (2016) The Economic Impact of Brexit-induced Reductions in Migration, London: NIESR.

Ritchie, J. and Lewis, J. (2013) Qualitative Research Practice: A Guide for Social Science Students and Researchers, London: SAGE.

Rienzo, C. (2015) Migrants in the UK Labour Market: An Overview, Migration Observatory, University of Oxford http://www.migrationobservatory.ox.ac.uk/wp-content/uploads/2016/04/Briefing-Migrants_ in_the_UK_Labour_Market.pdf [accessed 28.12.2016].

Rolfe, H., Rienzo, C., Lalani, M. and Portes, J. (2013) Migration and Productivity: Employers' Practices, Public Attitudes and Statistical Evidence, London: NIESR.

Rolfe, H., Portes, J. and Hudson-Sharp, N. (2016) Changing the Debate: Video Animation on the Impact of Immigration on the UK, Report to City of London, London: NIESR.

Ruhs, M. and Anderson, B. (2010) 'Migrant workers: who needs them? A framework for the analysis of staff shortages, immigration and public policy', in M. Ruhs and B. Anderson (eds.), Who Needs Migrant Workers? Oxford: Oxford University Press, 15-52.

Scott, S. (2013) 'Migrant-local hiring queues in the UK Food industry', Population, Space and Place, 19, 5, 459-71. 
Heather Rolfe

Somerville, W., Sriskandarajah, D. and Latorre, M. (2009) United Kingdom: A Reluctant Country of Immigration, Washington, DC: Migration Policy Institute.

Wadsworth, J. (2014) 'Immigration, the European Union and the UK labour market', Centre for Economic Performance (CEP) analysis, May 2014, http://cep.Ise.ac.uk/pubs/download/pa015.pdf [accessed 12.11.2016]. 